LSP International Journal, Vol. 6, Issue 2, 2019, 23-43

(C) Universiti Teknologi Malaysia

E-ISSN 2601-002X

DOI: https://doi.org/10.11113/lspi.v6n2.88

\title{
The Effect of Instructing Multi-word Verbs on EAP Learners' Presentation Skills: A Comparison with Native Academic Presentations
}

\author{
Nahla Salmani \& Mohammad Alipour \\ Department of English Language Teaching, Ahvaz Branch, Islamic Azad University, Ahvaz, Iran \\ Submitted: 1/08/2019. Revised edition: 29/10/2019. Accepted: 31/10/2019. Published online: 05/12/2019
}

\begin{abstract}
This study attempted to examine the effect of instructing multi-word verbs on intermediate EAP learners' presentations compared to native English speakers' academic presentations. To fulfill this end, 15 EAP learners were selected and delivered on presentation before and one after seven teaching sessions. Moreover, 15 native academic presentations were downloaded from YouTube. All the presentations were transcribed and then multi-word verbs were classified according to the coding measures presented by Biber et al. (1999) and Quirk et al. (1985) to disambiguate between the three chosen sub-categories of the study (phrasal verbs, prepositional verbs, phrasal prepositional verbs). The results obtained from this investigation reveal that there are significant differences in using multi-word verbs in natives and learners' presentations after treatment in terms of the preferred order, polysemy usage and the frequency. Although EAP learners were able to improve their use of these verbs in many aspects, they still differed from natives with respect to the preferred types and polysemous meanings of the verbs. The findings of this study have implications for EAP speaking classes, teachers, and learners.
\end{abstract}

Keywords: Multi-word verbs, Polysemy, Natives, EAP learners

\section{INTRODUCTION}

Nowadays, writing and speaking a foreign language like natives is the dream of many academic language learners. Unfortunately, not many learners are able to achieve this goal. The importance of learning collocations and multi-word verbs as reasons for becoming more proficient has been emphasized by many researchers (Wood, 2004; Folse, 2004). According to some studies, the most important feature in order to be fluent and native-like is to use expressions, idioms, collocations, different kinds of multi-word lexical verbs (phrasal verbs, prepositional verbs, phrasal prepositional verbs), prefabs, etc. (Moon, 1997; Wray, 2002). Mastering and comprehending the meaning of multiword verbs and collocations are essential for all English learners, not only in speaking or

*Correspondence to: Mohammad Alipour (email: alipour83@yahoo.com) 
comprehending their meanings, but also in listening and reading skills (Duan \& Qin, 2012). These structures are theme dependent and polysemous which lead to different meanings in different content and have a significant role in fluency and motivating learners (Maisa \& Karunakaran, 2013).

Language consists of chunks which are named formulaic language. Language is more than grammar and vocabulary; there are multi-word chunks, including idioms, proverbs, phrasal verbs, collocations and other prefabricated structures which play an important part in learners' fluency (Maisa \& Karunakaran, 2013). As we think of the meaning of collocations, learners' opinions allocate specific meaning to specific collocation as Firth (1957) introduced it for the first time. Collocations associate with other particle words in the sentence (Firth, 1957; Robins, 2000; Halliday \& Hasan, 2001). Halliday and Hasan (2001, p.317) argue that collocation is "the co-occurrence of lexical items that are in some way or other typically associated with one another, because they tend to occur in similar environments." It means that a word can imply other words and can be related to other meanings since they occur within the same theme and environment. For example, the word Night may be related to such words as Stars, Darkness, Sleeping, etc. It may also imply the gloomy condition in other environments. They overlap with the semantic theme and within the domain of the semantic field, they fit in a given environment, although the occurrence of a word may not cause the presence of others in that meaning domain (Duan \& Qin, 2012).

Many studies have established that multi-word verbs consist of a verb and one or two particles or prepositions (e.g. Up, Over, In, Down). These verbs are the most important features of the English language since they are used in almost all registers and are generally more common in conversations and academic presentations compared to academic writings (e.g., Biber, Johansson, Leech, Conrad \& Finegan, 1999; Siyanova \& Schmitt, 2007).

There are a lot of choices available in English for learners. One of these choices is between oneword verbs (discover the problem) and their multi-word verb equivalents (find out the problem). Multiword verbs are more idiomatic and tend to be used for more informal spoken conversations (Freeborn, 1995; Altenberg, 1998; Biber et al. 1999), particularly when compared to written language. On the other hand, one-word verbs tend to have a more formal form, and are thus more frequently used in non-spoken and less informal contexts, for instance, in academic usage and official written reports (Siyanova \& Schmitt, 2007).

Investigators advocate that English as an academic or second language learners (EAP/ESL) often have problems with multi-word verbs and try to avoid using them (Siyanova \& Schmitt, 2007). These verbs are problematic for English learners since they are semantically and syntactically flexible compared to other phraseological patterns (e.g. Variation of particle positions and pronoun or noun insertions are possible in multi-word verbs) For this reason, some researchers claim that English learners try to avoid using these items when they are communicating with others to overcome the communication problems. They also state that learners tend to use the easier structures and items because of this difficulty in their usage (Siyanova \& Schmitt, 2007; Houshyar \& Talebinejad, 2012).

Customarily, multi-word verbs are labelled as lexical multi-word verb structures that "behave as a single unit" (Quirk, Greenbaum, Leech \& Svartvik, 1985, p. 1150). Multi-word verbs are described as verb combinations which can be used in more than one context with probably more than one meaning. These verbs consist of a lexical verb followed by a preposition that make up a single unit 
with the verb semantically and syntactically (Biber et al., 1999). Multi-word expressions are characterized by a reduced processing load and easier semantic integration, as well as pre-activation of the mental template that uniquely matches the unfolding configuration. Further, they boost our understanding of the nature of the lexicon, contesting the lexicon-grammar dichotomy and offering support to frequency-based accounts of language acquisition, processing and use (Siyanova, Conklin, Caffarra, Kaan \& Heuven, 2017).

Multi-word lexical verbs may carry more than one meaning with regard to their polysemous aspect. In addition, they are complex and present difficulties for learners both in terms of their grammatical usage and their lexical meaning (Gardner \& Davies, 2007; Liu, 2011; Siyanova \& Schmitt, 2007). Through examining the literature, different classifications of phrasal verbs can be found. Phrasal verbs are classified into three groups; (1) literal phrasal verbs (e.g., go up) with direct implication concluded from the constituents, (2) figurative phrasal verbs (e.g., turn down) with a metaphorical variation of meaning and (3) completive phrasal verbs (e.g., burn down) with the related element to the involved action's outcome (Dagut \& Laufer, 1985). Another classification by Laufer and Eliasson (1993) suggests three kinds of phrasal verbs; (1) semantically transparent (the concept of the phrasal verb is known from its particle), (2) semitransparent (the meaning of the phrasal verbs can be understood in the context) and (3) semantically misty (the concept cannot be concluded from its particles and must be known as an idiom). Based on some studies, the semantically misty phrasal verbs which are known as idiomatic verbs are generally the most complicated verbs for English language learners and this is the reason why most learners try to avoid using them (e.g., Kamarudin, 2013; Houshyar Talebinezhad, 2012; You, 1999).

There are four major subcategories of multi-word verbs that comprise relatively idiomatic units and function like single verbs (phrasal verbs, prepositional verbs, phrasal prepositional verbs and free combinations) (Biber et al., 1999), which are defined in the following part. The first group is phrasal verbs which are multi-word units containing verbs followed by adverbial particles which all have spatial or locative meanings (e.g. Out, in, up, down). These verbs have two major subcategories, they could be intransitive (e.g. Come on, break down, etc.) Or transitive (carry out, take out, etc.) They are frequently used with different meanings, and syntactically can be transitive or intransitive (Biber $e t$ al., 1999). Intransitive phrasal verbs are mostly known as verbs of action in sentences and phrases (Biber, Conrad \& Leech, 2002, p. 128). Single word verbs with the same meaning of phrasal verbs are often regarded as more formal. However, phrasal verbs are more powerful in native-like speaking and conversations and they have been widely researched as they have been found particularly problematic for second language learners of English since they cannot easily guess their meanings from their individual parts (e.g., Chen, 2013; Gardner \& Davies, 2007; Liu, 2011; Siyanova \& Schmitt, 2007).

The second main type of multi-word verbs are prepositional verbs (e.g., ask about). They are composed of a verb followed by a preposition, such as deal with, talk about, ask for, etc. These verbs contain both an adverbial particle and a preposition, as in get away with. Some of these structures can be separated and the other cannot be separated (Quirk et al., 1985; Biber et al., 1999). The preposition part of them is commonly followed by a noun or pronoun. They are generally lexically individually stressed. The primary stress is on the verb, while the second element which is the preposition, does not get emphasized and it is being unstressed (except for contrastive emphasis) (Wells, 2006). In other words, both words in the arrangement may maintain their exact meaning to a 
changeable extent and there is a relatively static relation between the verb and the preposition. We can separate these prepositional verbs in two types: Type I: verb + preposition + (NP), here the NP which comes after the preposition is known as a complement (object) of the preposition (e.g., She talked about it before.) And Type II structures: verb + object + prepositional phrase (PP) (e.g., She reminds me of my mother) in this way the proposition is chosen by the verb, not by free semantic reasons (Quirk et al., 1985).

The third type of multi-word verbs which have the features of both phrasal and prepositional verbs are phrasal prepositional verbs (e.g., come up with = to think of an idea/answer). They consist of a lexical verb combined with an adverbial particle and a preposition. [Type I]; I'm going to let you in on a little secret. [Type II]. The symbol of their colloquial position is the possibility of a single-verb rephrase of the phrasal-prepositional structure (e.g., Watch out for that man (= to care for him and see if he's feeling any better) (Zareva, 2016).

Idiomatic verbal lexes of various structures and complexity can be named as the last subcategory of "other" which consists of complicated combinations, called free combinations. This subcategory was eliminated from the study because of its syntactically less dependable than the other three subcategories, and it is not frequently used in daily language usage that might be one of the details which makes it less studied than the other three subcategories (Zareva, 2016).

In particular, the present study will not be concerned with free combination multi-word verbs, because of its relative influence on language use and academic style. This also means that the term multi-word verbs will be used in this study in order to refer to those three main multi-word verb constructions; phrasal, prepositional, and phrasal prepositional verbs.

\section{STATEMENT OF PROBLEM AND PURPOSE}

Collocations and multi-word verbs form an important aspect of vocabulary acquisition, though some of them might be easily acquired because of their extra-linguistic structure and dealing with verbal contexts that we consider only linguistic factors, such as hot chocolate, warm bath, etc. They are noticeably connected to the referential meanings of the related words (Robins, 2000). Words are always used together and there is a meaningful relation between them. They always present themselves in collocations which are a general linguistic occurrence. It is not an overstatement to claim that every natural language has collocations. In fact, "words seldom occur in isolation" (Wallace, 1982, p.30). Collocation is not only a necessary element of language, but also an outstanding feature that makes language more specific and accurate. Therefore, to learn English well, learners should put much importance to collocation (Duan \& Qin, 2012).

The most prominent feature of the English language that has been found to be used in all registers is multi-word verb structures, though, generally, they are used more in conversational registers rather than academic writing registers (e.g., Biber et al., 1999; Siyanova \& Schmitt, 2007). Findings on multiword verbs, suggest that phrasal verbs can enhance the English language proficiency (Riguel, 2014). 
Studies have revealed that multiword verbs which are closely similar to collocations can also provide benefits to second language learners. Customarily, multi-word verbs were defined as lexical multiword verb constructions that act as an independent unit. (Quirk et al., 1985). Recent corpus studies have suggested that multi-word verbs are more predominant in language than previously thought, with these verbs comprising 20-50\% of all languages (Erman \& Warran, 2000; Biber \& Conrad, 1999). A number of investigations on second language learners show that multi-word verbs enhance the speed of encoding and decoding language and hence fluency (Ellis, 1996; Wood, 2004). Some other researchers claimed that awareness of functional multiword expressions, such as those used to explain meaning or manage discourse, develops pragmatic competence, giving instant communicative benefits even to lower proficiency-level learners (Lewis, 1993; Nattinger \& Decarrico, 1992).

There is great confusion with regard to teaching approaches of multiword verbs and the most useful ones which should be taught (Condon \& Kelly, 2002; Darwin \& Gray, 1999; Nesselhauf, 2003). Through some studies, multiword chunks have received great attention from teachers in order to improve the learners' native-like fluency in many ways, by teaching idioms, phrasal verbs, stock phrases, prefabs, highly used expressions and multiword structures which give a sense of elegance and admirability to the language (Moon, 1997; Schmitt, 2004; Wray, 2000, 2002).

When learners learn the grammatical constructions of the language and are capable of producing such structures appropriately, the most feasible way for them to progress and to reach the progressive level of language proficiency is to learn more collocations and multiword structures compared to dealing with grammar only, since these structures help learners to have native-like proficiency of expressions (Lewis, 2001; Wan Nur Asyura \& Maskanah, 2017).

There might be no simultaneous for most collocations. Dissimilar words might be known by the same conceptual meaning. The unclear behavior of collocations needs more attention from both teachers and learners of English. For teachers, collocations and multiword expressions should be an essential portion of vocabulary teaching and colloquial meanings of them should be given to learners. English learners must know the importance of idiomatic structures in word acquisitions and give a great consideration for their accurate use in order to have a good speech (Duan \& Qin, 2012).

A range of studies have manifested that multiword expressions, particularly phrasal verbs, can enhance the English language proficiency (Riguel, 2014). Swales (2004) and Biber (2006) have noted that academic presentations in the U.S. are more informal and interactive compared to academic writing. In addition, instructors regularly integrate different communicative activities in transporting their informational content and university students are expected to involve in transporting of informational content among diverse academic genres in a suitable way. Among the genres, the one they are usually dealing with at both undergraduate and graduate level of their educational path is the academic presentation.

Some corpus studies compared the oral and written academic registers (e.g., Biber, 2006; Carter-Thomas \& Rowley-Jolivet, 2001; Swales, 2004; etc.). Some others were conducted on oral academic discourse produced by students and experts, counting conference papers (Rowley-Jolivet, 1999; Thompson, 2002; Ventola, Shalom \& Thompson, 2002; Webber, 2005), graduate student seminars (Weissberg, 1993), metatalk (Swales, 2001), lectures (Crawford- Camiciottoli, 2004) and evaluation in academic talk (Mauranen, 2002), university classroom talk (Csomay, 2006; 2007), student powerpoint presentation designs (Zareva, 2011), and student presentations (Boyd,1989; 
Csomay, 2015; Morton \& Rosse, 2011; Zareva, 2009a, 2009b, 2012a, 2012b, 2013). Most of these studies were mainly concerned with each of the academic registers or a particular genre through a specified register, on the one hand, to give better preparation of language-specific task strategies, feedback, suggestions, and recommendation to their learners upon research findings compared to prescriptive 'tips' or private intuitions. On the other hand, they try to raise students' awareness of the differences between the oral and written registers and, correspondingly, the genres in which they are expected to perform academically (Zareva, 2016).

There are a lot of difficulties with using multi-word verbs. Some of these multiword verbs such as put off, run into, and come up with, consist of two or more orthographic words working together at its basic level, making them hard to be considered as a single semantic unit (Dagut \& Laufer, 1985; Hulstijn \& Marchena, 1989; Laufer \& Eliasson, 1993; Granger, 1998; Liao \& Fukuya, 2004). Besides the proficiency of decoding the meanings of the individual words by learner, multi-word verbs must be acquired, kept and recovered from the mind for learners' usage (Wray \& Perkins, 2000).

Another significant problem for non-native learners is the meaning of these verbs that might vary from their superficial meaning. Some of them can be easily known from their individual units (so call back in ten minutes $=$ To return a phone call); however, some others are virtually inconceivable (iron out their differences $=$ To resolve by discussion) . Another complication of multi-word verbs is their idiomatic meaning, so that these meanings do not match the meaning of the individual words in the verb. The most complicated part in their meaning is the polysemous ones (bring up the tools from the basement $=$ carry them up; bring up children $=$ nurture; bring up a suggestion $=$ mention $)$, in which a learner may encounter more than one meaning for one multi-word verb (Biber et al. 1999). About five percent of phrasal verbs have more than one meaning which makes them polysemous (Moon, 1998).

The most comprehensively researched subcategory of multi-word verbs are phrasal verbs which have been found problematic to master for EFL and ESL learners (e.g., Chen, 2013; Gardner \& Davies, 2007; Liu, 2011; Siyanova \& Schmitt, 2007). The general agreement among researchers is that phrasal verbs are functionally beneficial in various contexts and registers, and they are a noticeable feature of the English language since the repeated use of natural language might deal with their polysemous feature (Gardner \& Davies, 2007; Liu, 2011; Siyanova \& Schmitt, 2007).

According to the research on the British National Corpus (BNC) (a 100-million-word corpus of spoken and written British English), Gardner and Davies (2007) claim that a person could meet one phrasal verb in every 192 words of text on average. Liu (2011) conduct a phrasal verb investigation using the Contemporary Corpus of American English (COCA) (Davies, 2008) and determined that the repartition designs in both American and British English corpora are alike. His outcomes confirmed Biber et al.'s (1999) conclusions about the repartition designs of phrasal verbs among the records in that the phrasal verbs were four to five times more prominent in spoken language (approx. 5,200 per million) than academic written discourse (approx. 1,200 per million).

There have been many studies on different aspects of academic presentations, though it seems that not enough attention has been given to how multi-word verbs can effectively shape academic presentations as more fluent and proficient speeches. The different subcategories of multi-word verbs have been quite randomly orientated in the research literature. There are a number of studies on 
phrasal verbs, but the prepositional and phrasal prepositional ones have received little attention in the literature (Zareva, 2016).

Although some studies have attempted to assess the relative impression of the three subcategories of multi-word verbs—prepositional, phrasal, and phrasal prepositional—on students' academic presentations, it seems that few studies have been conducted to introduce methods in teaching these verbs. Moreover, no comparison has been conducted between the frequency of using multi-word verbs in native and non-native academic presentations. Another important point with no attention is the preferred meaning of these verbs among native and non-native speakers. As it is understood, few investigations have been conducted with regard to multi-word verbs in non-native learner presentations (Zareva, 2016; Chen, 2013); therefore, this study aims to show whether teaching multi-word verbs for academic presentation can improve EAP learners' use of these verbs and as such their presentation ability. This will be carried out via comparing these verbs in native presentations as a norm and non-native learners' presentations to examine the following questions:

1. Is there any significant difference between natives and EAP learners' presentations in the frequency of multi-word verbs?

2. What is the order of preferred usage of multi-word verb combinations in natives and learners' presentations?

3. Does instruction of multi-word verbs affect their use by EAP learners?

\section{METHOD}

\section{Corpus}

The study relied on 15 academic presentations selected from university presentations by native speakers. Fifteen native speakers' presentations were downloaded from YouTube. Since we did not have access to native presentations, we sought the presenters' permission via email. All the native presentations were transferred from HD videos into MP4 files and then transcribed. The presentation topics were on different social issues. According to the following table, each presentation comprised 2248 words on average, ranging from 15 to 19 minutes. The second group of presentations entailed 30 presentations by EAP learners. Fifteen presentations, each 15 to 20 minutes, were given before the treatment as a pre-test, and on average 2071 words were recorded. After the treatment, 15 other presentations were delivered by the same learners to check the effect of teaching multi-word verbs on their presentations. Averagely, 2272 words were presented in each presentation of 15 to 20 minutes. The following table is related to the detailed information for the presentations. 
Table 1 Details of Presentations

\begin{tabular}{|c|c|c|c|c|c|c|}
\hline \multirow[b]{2}{*}{$\begin{array}{l}\text { Lecture } \\
\text { number }\end{array}$} & \multicolumn{2}{|c|}{ Natives Presentations } & \multicolumn{2}{|c|}{$\begin{array}{l}\text { Learners Presentations } \\
\text { (Before Treatment) }\end{array}$} & \multicolumn{2}{|c|}{$\begin{array}{c}\text { Learners Presentations (After } \\
\text { Treatment) }\end{array}$} \\
\hline & Time & $\begin{array}{l}\text { Number of } \\
\text { words }\end{array}$ & Time & $\begin{array}{l}\text { Number of } \\
\text { words }\end{array}$ & Time & $\begin{array}{l}\text { Number of } \\
\text { words }\end{array}$ \\
\hline Lecturel & $15 \mathrm{~min}$ & 2181 & $15 \mathrm{~min}$ & 2003 & $15 \mathrm{~min}$ & 2116 \\
\hline Lecture2 & $17 \mathrm{~min}$ & 2335 & $16 \mathrm{~min}$ & 2098 & $15 \mathrm{~min}$ & 2061 \\
\hline Lecture3 & $16 \mathrm{~min}$ & 2257 & $16 \mathrm{~min}$ & 2111 & $15 \mathrm{~min}$ & 2038 \\
\hline Lecture4 & $18 \mathrm{~min}$ & 2428 & $18 \mathrm{~min}$ & 2213 & $15 \mathrm{~min}$ & 2076 \\
\hline Lecture5 & $15 \mathrm{~min}$ & 2120 & $15 \mathrm{~min}$ & 2010 & $17 \mathrm{~min}$ & 2250 \\
\hline Lecture6 & $15 \mathrm{~min}$ & 2087 & $15 \mathrm{~min}$ & 2018 & $15 \mathrm{~min}$ & 2198 \\
\hline Lecture7 & $18 \mathrm{~min}$ & 2672 & $18 \mathrm{~min}$ & 2231 & $18 \mathrm{~min}$ & 2419 \\
\hline Lecture8 & $15 \mathrm{~min}$ & 2194 & $15 \mathrm{~min}$ & 1989 & $17 \mathrm{~min}$ & 2203 \\
\hline Lecture9 & $19 \mathrm{~min}$ & 2976 & $17 \mathrm{~min}$ & 2153 & $18 \mathrm{~min}$ & 2352 \\
\hline Lecture10 & $16 \mathrm{~min}$ & 2281 & $16 \mathrm{~min}$ & 2086 & $15 \mathrm{~min}$ & 2181 \\
\hline Lecturell & $15 \mathrm{~min}$ & 2069 & $15 \mathrm{~min}$ & 2008 & $20 \mathrm{~min}$ & 2639 \\
\hline Lecture12 & $15 \mathrm{~min}$ & 2063 & $15 \mathrm{~min}$ & 2021 & $19 \mathrm{~min}$ & 2609 \\
\hline Lecturel3 & $15 \mathrm{~min}$ & 2050 & $16 \mathrm{~min}$ & 2147 & $16 \mathrm{~min}$ & 2123 \\
\hline Lecture14 & $15 \mathrm{~min}$ & 1994 & $15 \mathrm{~min}$ & 1994 & $18 \mathrm{~min}$ & 2433 \\
\hline Lecturel5 & $15 \mathrm{~min}$ & 2006 & $15 \mathrm{~min}$ & 1979 & $17 \mathrm{~min}$ & 2376 \\
\hline
\end{tabular}

\section{Participants}

The study was based on the presentations of a group of second language English-speaking college students. The non-native data were compared to 15 native speakers' presentations and then 15 participants were chosen out of 45 Iranian male and female English learners whose ages ranged from 20 to 35 years. Intermediate learners were selected among EAP students at Islamic Azad University of Ahvaz through their performance on the Quick Oxford Placement Test (QOPT). The selected participants presented 15-to-20-minute presentations as the pre-test. They were then instructed on the application of multi-word verbs in presentations as the treatment to boost their abilities in using these verbs while speaking. After the mentioned treatment, each learner gave another presentation in 15 to 20 minutes to tease out the effect of teaching multi-word verbs. The final data of the study after the treatment were compared with the recorded presentations before the treatment and also the native presentations. 


\section{Instruments and Materials}

The participants' presentations were recorded with a voice recorder to investigate the produced multiword verbs. Text analysis software was employed in this study called Nooj. Nooj is a free downloadable software (available at http://www.nooj4nlp.net/pages/nooj.html) to identify the particles and prepositions in a text. A corpus processing system that is NET application can be used to identify morpho-syntactic patterns, lemmatized concordances, etc. It was used to analyze these verbs in two groups. The results were presented in a KWIC (key word in context) output that could be exported into an editable file format. The following figure illustrates a sample of KWIC.

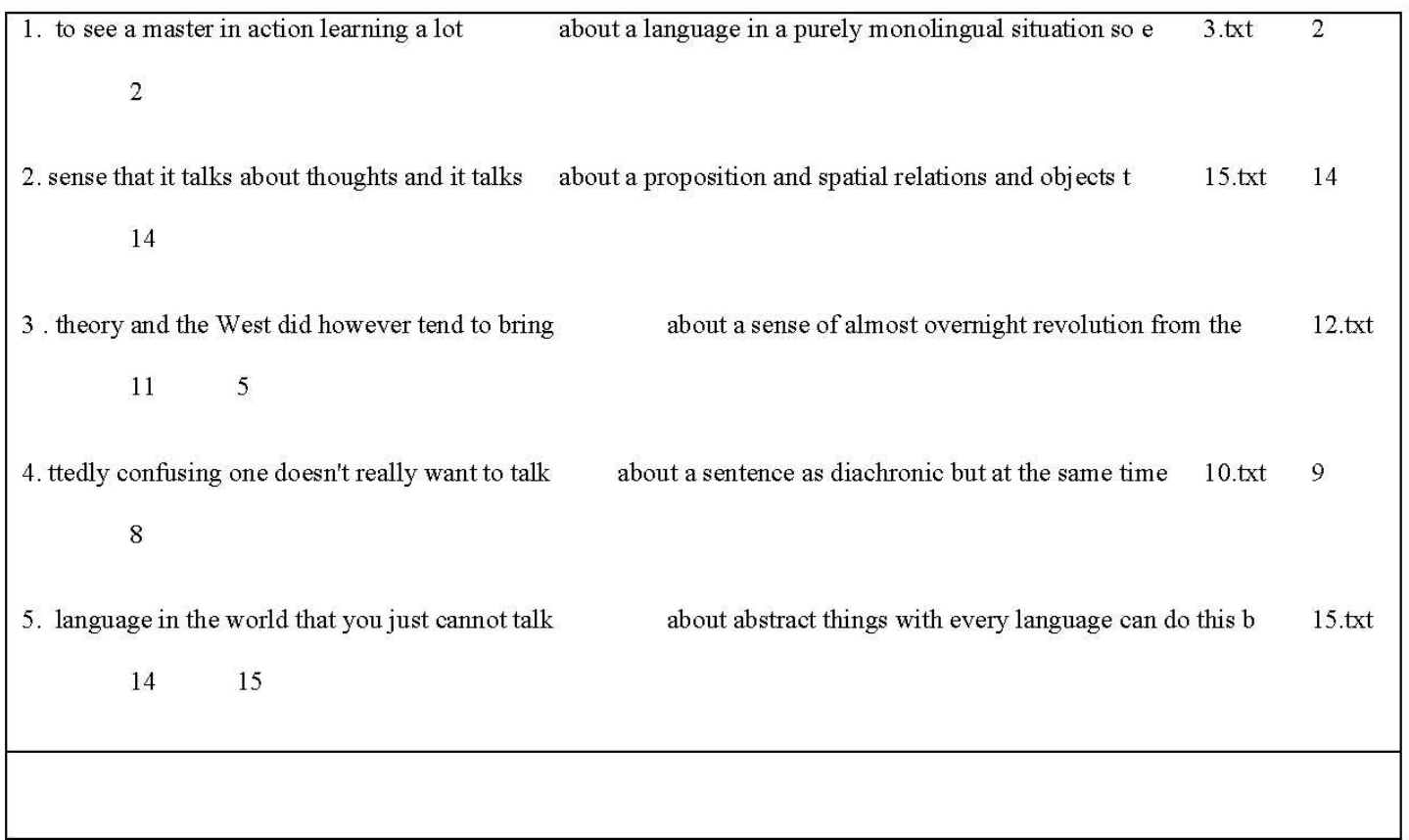

Figure 1 Editable File Format of Nooj

The following coding measures were dveloped by Biber et al. (1999) and Quirk et al. (1985) and were employed to disambiguate between the sub-categories in this study:

1. Phrasal verbs: dictionaries seem to use phrasal verbs as a primary standard for the identification of phrasal verbs, and through this study the semantic standard will be given a higher priority than the syntactic one.

2. Prepositional verbs: they are considered as a verb followed by a preposition, such as look after, look into, take after, ask for, etc. These verbs may include both an adverbial particle and a preposition, as in get away with. 
3. Phrasal prepositional verbs: In this category, the verb is followed by an adverbial particle and a preposition is coded as phrasal prepositional verb. They are Threemember verb series and the combination should be assured by a certain degree of idiomaticity (e.g., I'll catch up with you later).

\section{Procedure}

After searching for native speaker's presentations and according to the presenters' permission, presentations were downloaded and transcribed. Specified categories were drawn out through the text with Nooj. Then, the identification of the multi-word verbs generated in whole corpus, and the frequency, preferred meaning and the favored order of native learners' usage were investigated. The EAP students were asked to present their presentations in 15 to 20 minutes in class before a small number of their classmates. Iranian presentations were transcribed and compared with native speakers in terms of their frequency, preferred order, and polysemy differences of using multi-word verbs.

After distinguishing the differences, the second phase of presentations were given after seven 90-minute teaching sessions to EAP learners which were conducted in order to help them to have a better understanding of these verbs, and to assess them in using multi-word verbs intelligibly in their presentations. The effectiveness of the treatment was in their presentations. The teaching courses were administered twice a week and almost 3 hours per week. Through the instruction, explicit teaching method was applied and the native presentations were played to show how multi-word verbs is being used by natives in academic presentations. In addition, some trainings and demos were presented as a part of their practice by learners in the mentioned sessions to control their weaknesses and the way of using these verbs. Their second presentations were also recorded and transcribed for more precise comparison. Students were permitted to use notes and were encouraged to arrange visuals like PowerPoint and handouts while presenting.

The data analysis was to double-check the status of the recognized multi-word verbs with regard to three dictionaries, namely Oxford English Dictionary, Longman Dictionary of Contemporary English, and Cambridge Dictionaries. Through the data analysis of the investigation, Oxford English Dictionary was used as a main source in the categorization process, as it is the most comprehensive dictionary of the three mentioned sources. Additionally, all structures were also checked through Longman Dictionary of Contemporary English and Cambridge Dictionaries to ensure if they were known as one of the three main categories of multi-word verbs. Typically, there was nearly 80 percent similarities between the position of prepositional and phrasal verbs and only roughly 8 percent on the position of phrasal prepositional verbs on the dictionaries.

After analyzing the multi-word verbs in presentations, the frequency count was made in the use of these verbs and Chi-Square test was performed to determine if there were any significant differences between the use of multi-word verbs in native and non-native presentations and also for comparing native presentations and learner presentations after and before the mentioned treatment. 


\section{RESULTS}

The findings related to multi-word verbs were obtained in terms of their frequencies and occurrences in the native and non-native learner presentations. We conducted a pre-test and post-test among EAP learners to see the difference in EAP learners' presentations before and after the mentioned treatment. A total number of 237 multi-word verbs were recognized in 31,061 words transcribed from EAP learners' presentations as the pre-test. Furthermore, a post-test was run after the instruction and 1,156 multi-words were identified in 34,074 words transcribed from EAP learners' post-test. Table 2 manifests the frequency, polysemy and preferred order of the multi-word verbs used in the presentations as pre-test and post-test. According to the results from the Chi-Square tests and frequencies, we can discuss that there was a substantial improvement in EAP learners' performance after the treatment sessions.

Table 2 Results for Multi-Word Verbs in EAP Learner's Presentations (Pre-Test and Post-Test)

\section{EAP Learners Before Treatment}

Phrasal verb ( frequency ) Prepositional verb (frequency)
(frequency)

$\mathbf{8 9}(\mathbf{3 7 . 5 5 \% )}$

$143(60.33 \%)$

$5(2.1 \%)$

\begin{tabular}{cccccc}
\hline Separable & Inseparable & Separable & Inseparable & Separable & Inseparable \\
\hline $\mathbf{8 ( 8 . 9 8 \% )}$ & $81(91.01 \%)$ & $5(3.49 \%)$ & $138(96.50 \%)$ & $0(0 \%)$ & $5(100 \%)$ \\
\hline $\begin{array}{c}\text { Same } \\
\text { meaning }\end{array}$ & $\begin{array}{c}\text { Different } \\
\text { meaning }\end{array}$ & $\begin{array}{c}\text { Same } \\
\text { meaning }\end{array}$ & $\begin{array}{c}\text { Different } \\
\text { meaning }\end{array}$ & Same meaning & Different meaning \\
\hline $\mathbf{8 9}(\mathbf{1 0 0 \% )}$ & $0(0 \%)$ & $143(100 \%)$ & $0(0 \%)$ & $5(100 \%)$ & $0(0 \%)$
\end{tabular}

EAP Learners After Treatment

Phrasal verb ( frequency ) Prepositional verb (frequency) $\quad \begin{gathered}\text { Phrasal prepositional verb } \\ \text { (frequency) }\end{gathered}$

$\begin{array}{lll}\mathbf{5 5 5}(\mathbf{4 8 . 0 1 \% )} & 546(47.23 \%) & 55(4.75 \%)\end{array}$

\begin{tabular}{cccccc}
\hline Separable & Inseparable & Separable & Inseparable & Separable & Inseparable \\
\hline $\mathbf{6 0}(\mathbf{1 0 . 8 1 \% )}$ & $495(89.18 \%)$ & $33(6.04 \%)$ & $513(93.95 \%)$ & $1(1.81 \%)$ & $54(98.18 \%)$ \\
\hline $\begin{array}{c}\text { Same } \\
\text { meaning }\end{array}$ & $\begin{array}{c}\text { Different } \\
\text { meaning }\end{array}$ & $\begin{array}{c}\text { Same } \\
\text { meaning }\end{array}$ & $\begin{array}{c}\text { Different } \\
\text { meaning }\end{array}$ & Same meaning & Different meaning \\
\hline $\mathbf{5 5 5}(\mathbf{1 0 0 \% )}$ & $0(0 \%)$ & $546(100 \%)$ & $0(0 \%)$ & $55(100 \%)$ & $0(0 \%)$
\end{tabular}


As we can see in the above table, there is a remarkable difference in using the cited verbs in EAP learner presentations before and after the teaching sessions. The analysis of the results after the treatment shows a dramatic growth in using phrasal verbs to 48 percent and phrasal-prepositional to 4.75 percent. However, there was a marginal decrease in using prepositional percentage $(47.23 \%)$. Table 2 displays an increase in using phrasal verbs $(89.18 \%)$, prepositional verbs (93.95\%), and phrasal-prepositional $(98.18 \%)$ in an inseparable way in learner's presentations after the treatment, although learners favored the same meaning over different meanings in all the three categories even after the instruction. The comparison of EAP learners' test results also reveals that learners tend to employ the three subcategories with single meanings before and after the instruction, while the natives use them in polysemous ways as demonstrated below. In addition, learners barely use separable verbs; however, natives use them in both ways with a greater focus on inseparable verbs.

Table 3 Chi-Square Tests of Overall Comparison of EAP Learner's Pre-test and Post-Test

\begin{tabular}{llll}
\hline & Value & Df & Asymp. Sig. (2-sided) \\
Chi-Square & $14.684^{\text {a }}$ & 2 & .001 \\
& & &
\end{tabular}

a. 0 cells (.0\%) have expected count less than 5. The minimum expected count is 10.21.

The chi-square test of the comparison between EAP learners' pre-test and post-test indicates that there is a significant difference (.00) in the frequency of using multi-word verbs before and after the given instruction. The outcomes of the study reveal that the EAP learners could use the three subcategories with much greater frequencies than before the treatment.

Table 4 Standard Residuals for EAP Learner's Pre-test and Post-Test

\begin{tabular}{|c|c|c|c|}
\hline & \multicolumn{2}{|c|}{ EAP Learners } & \multirow[t]{2}{*}{ Total } \\
\hline & Before & After & \\
\hline Phrasal verbs & 89 & 555 & 644 \\
\hline Prepositional verbs & 143 & 546 & 689 \\
\hline Phrasal-prepositional verbs & 5 & 55 & 60 \\
\hline Count & 237 & 1156 & 1393 \\
\hline
\end{tabular}

As can be understood from Table 4, the standard residual in the first row for phrasal verbs indicates that the differences between the EAP learners' pre-tests and post-tests are remarkable (EAP learner's pre-test $=-2.0$, EAP learner's post-test $=.9)$, in addition, the same is true for the second 
subcategory that are prepositional verbs $($ EAP learner's pre-test $=2.4$, EAP learner's post-test $=-1.1)$. Nonetheless, there are not any meaningful differences in the third subcategory, phrasal-prepositional verbs (EAP learner's pre-test $=-1.6$, EAP learner's post-test $=.7$ ).

In order to check the effectiveness of the given instruction, we compared the results of the native speakers with EAP learners after the treatment.

Table 5 Results for Multi-Wod Verbs in Native and EAP Learner's Post-Test Presentations

\section{Native presentations}

\begin{tabular}{|c|c|c|c|c|c|}
\hline \multicolumn{2}{|c|}{ Phrasal verb ( frequency ) } & \multicolumn{2}{|c|}{ Prepositional verb (frequency) } & \multicolumn{2}{|c|}{$\begin{array}{l}\text { Phrasal prepositional verb } \\
\text { (frequency) }\end{array}$} \\
\hline \multicolumn{2}{|c|}{$527(40.56 \%)$} & \multicolumn{2}{|c|}{$689(53.04 \%)$} & \multicolumn{2}{|c|}{$83(6.3 \%)$} \\
\hline Separable & Inseparable & Separable & Inseparable & Separable & Inseparable \\
\hline 148(28.08\%) & $379(71.91 \%)$ & $116(16.83 \%)$ & $573(83.16 \%)$ & $18(21.68 \%)$ & $65(78.31 \%)$ \\
\hline $\begin{array}{c}\text { Same } \\
\text { meaning }\end{array}$ & $\begin{array}{l}\text { Different } \\
\text { meaning }\end{array}$ & $\begin{array}{c}\text { Same } \\
\text { meaning }\end{array}$ & $\begin{array}{l}\text { Different } \\
\text { meaning }\end{array}$ & Same meaning & Different meaning \\
\hline $452(85.76 \%)$ & $75(14.23 \%)$ & $671(97.38 \%)$ & $18(2.61 \%)$ & $83(100 \%)$ & $0(0 \%)$ \\
\hline
\end{tabular}

\section{Learner presentations after treatment}

$\begin{array}{cc}\text { Phrasal verb ( frequency ) Prepositional verb (frequency) } & \begin{array}{c}\text { Phrasal prepositional verb } \\ \text { (frequency) }\end{array}\end{array}$
(frequency)

$\mathbf{5 5 5}(\mathbf{4 8 . 0 1 \% )} \quad 546(47.23 \%) \quad 55(4.75 \%)$

\begin{tabular}{cccccc}
\hline Separable & Inseparable & Separable & Inseparable & Separable & Inseparable \\
\hline $\mathbf{6 0}(\mathbf{1 0 . 8 1} \%)$ & $495(89.18 \%)$ & $33(6.04 \%)$ & $513(93.95 \%)$ & $1(1.81 \%)$ & $54(98.18 \%)$ \\
& & & & & \\
\hline $\begin{array}{c}\text { Same } \\
\text { meaning }\end{array}$ & $\begin{array}{c}\text { Different } \\
\text { meaning }\end{array}$ & $\begin{array}{c}\text { Same } \\
\text { meaning }\end{array}$ & $\begin{array}{c}\text { Different } \\
\text { meaning }\end{array}$ & Same meaning & Different meaning \\
\hline $\mathbf{5 5 5 ( \mathbf { 1 0 0 } \% )}$ & $0(0 \%)$ & $546(100 \%)$ & $0(0 \%)$ & $55(100 \%)$ & $0(0 \%)$
\end{tabular}

The results indicate that instruction had a positive effect on EAP learners. As we can see in Table 5, EAP learners are almost similar with natives speakers in the frequency of using multi-word verbs. It manifests 1,156 multi-word verbs in 3,474 words of EAP learners' presentations after the 
treatment while there is a total number of 1,299 multi-word verbs in 33,713 words in the native corpus. There is a great similarity in natives and EAP learner's academic presentations after the treatment.

Table 6 Chi-Square Tests of Overall Comparison of Natives and EAP Learners Presentations after Treatment

$\begin{array}{llll} & \text { Value } & \text { Df } & \text { Asymp. Sig. (2-sided) } \\ \text { Chi-Square } & 14.684^{\mathrm{a}} & 2 & .001 \\ & & & \end{array}$

a. 0 cells (.0\%) have expected count less than 5. The minimum expected count is 48.73 .

As we can see in Table 6, the chi-square test points out that there is a significant difference (.00) in using multi-word verbs between natives and EAP learners after the treatment. We can see that despite EAP learners' improvement in using multi-word verbs in their presentations after some sessions of treatment, they still differed significantly from native use of these verbs in their presentations.

Table 7 Standard Residuals for Native and EAP Learner's Post-Test Presentations

\begin{tabular}{lcccc}
\hline & & \multicolumn{2}{c}{ Total } & \\
\cline { 3 - 4 } & & & & \\
& Native & Non-native & \\
& Phrasal verbs & 527 & 555 & 1082 \\
Std. Residual & -1.9 & 2.0 & \\
\hline Prepositional verbs & 689 & 546 & 1235 \\
Std. Residual & 1.4 & -1.5 & 138 \\
\hline Total & Phrasal-prepositional verbs & 83 & 55 & \\
\hline & Std. Residual & 1.2 & -1.2 & 2455 \\
\hline
\end{tabular}

As can be observed from Table 7, the standard residual between phrasal verbs in the first row shows that the differences between natives speakers and EAP learners were not noticeable (native corpus $=-1.9$, Iranian non-native $=2.0$ ), while it was significant for the second subcategory (native corpus $=1.4$, Iranian non-native corpus $=-1.5$ ), and the third subcategory (native corpus $=1.2$, Iranian non-native corpus $=-1.2$ ). 


\section{DISCUSSION}

The main purpose was to examine the use of multi-word verbs before and after the mentioned instruction and to compare them with natives' use of multi-word verbs. The analysis identified a boundless difference in using multi-word verbs before and after the treatment for all the investigated aspects like frequency, preferred order and polysemous. Findings showed that all EAP learners were unable to use the subcategories separably and polysemously. Native speakers employ both separable and inseparable verbs, but EAP learners are not able to use these verbs with different meanings as the natives do. They preferred using these verbs mostly with single meaning even after the instruction was given to them since these multi meaning verbs may confuse and cause ambiguity for them. The frequency of using multi-word verbs has changed prominently in the three subcategories as the EAP learners have learned how to use multi-word verbs in their presentations and tried using them in training sessions. Findings reveal that the frequency of the used phrasal verbs by EAP learners improved compared with the pre-test. They were able to use them in both separable and inseparable ways, though unlike the natives speakers since natives' percentage of using separable phrasal verbs was higher than EAP learners even after the treatment. We can shed light on the difficult aspects of using the separable verbs by EAP learners since after less than ten sessions, we cannot expect the learners to use these verbs same as natives. As mentioned earlier, the learners may face many structural difficulties to use them with direct object or indirect one or even with the place of the object and the pronoun.

The research literature has addressed different subcategories of multi-word verbs unevenly. Phrasal verbs have received attention in previous studies, but prepositional and phrasal prepositional ones have received little attention. The study between natives and EAP learners revealed that there is a remarkable difference in using multi-word verbs between their presentations since natives use multiword verbs more than learners. However, this difference is not restricted to their frequency since most non-natives often have problems with multi-word verbs (Siyanova \& Schmitt, 2007). These verbs are problematic for non-native learners since they are semantically and syntactically changeable compared to other phraseological patterns. For this reason, some researchers claim that non-native English speakers try to avoid using these items when they are communicating with others to overcome the communication problems. They also claim that non-natives tend to use the easier constructions and items because of this difficulty in their usage (Siyanova \& Schmitt, 2007; Houshyar \& Talebinejad, 2012).

There is avoidance towards the production of multi-word verbs when EAP learners need to provide fluent and accurate sentences. They prefer to use one-word verbs since they are easier to be used. For instance, they prefer the verb discover over the phrasal verb find out and apply many other one-word verbs instead of prepositional and phrasal-prepositional verbs.

The favored usage order of the three subcategories (phrasal verbs, prepositional verbs, and phrasal-prepositional verbs) was also investigated and a great difference was noticed among the natives and EAP learners. The data seem to advocate that natives tend to use these verbs in separable and inseparable order, conversely EAP learners tend to use multi-word verbs more in the inseparable order since it might be a much easier order for many learners. Results revealed that learners could not use multi-word verbs in the same order as natives since the particle and preposition used with verb are 
harder to be used; for example, when the direct object is the specific name of a thing or person, it can be located after the phrasal verb or in the middle (e.g., I threw away the old texts $=$ I threw the old texts away). However, when the direct object is a pronoun (me, you, him, her, us, them, it), it must be placed in the middle (I threw it away.) and not located after the phrasal verbs (I threw away it). Based on the evidence and the sentences used in non-natives' presentations, we can deduce that distinguishing the separable and inseparable multi-word verbs and the direct or indirect object placement in a sentence might be the main reason for learners' problems in using these verbs.

We also attempted to examine whether EAP learners used polysemous multi-word verbs in a similar way to the natives, and the results presented that learners are unable to manage using almost all the three subcategories of multi-word verbs in polysemous ways, unlike natives who use them with single and polysemous meanings. The results suggest that this polysemous feature which leads to semantic difficulty of phrasal verbs has led in the avoidance behavior of learners (Fadanelli, 2012; Houshyar \& Talebinezhad, 2012). The semantic investigation of the multi-word verbs in this study and other studies (Zareva, 2016) indicates that even though the majority of them had several meanings, they were mostly used with a single meaning in learner presentations. With regard to this, establishing a set of senses for polysemous verbs is notoriously hard since the meaning is very often determined in the context, and it depends to some extent on semantics of the arguments as compared to the base meaning of the verb itself. Often, collections of related meanings exist and the meanings are extended. Most of these verbs have no meaning-related structures and this has caused problems to EAP learners.

\section{CONCLUSION}

Results have demonstrated that EAP learners could improve their use of multi-word verbs and reach more native like proficiency in their academic presentations, especially in terms of their frequency. However, the favored order and using verbs with polysemous features still apeared to be syntactically and semantically problematic for EAP learners. Although this is only a slim majority, this inquiry supports previous hypothesis made on the field which indicates that avoidance behavior of using multi-word verbs is due to both structural and semantic difficulties of them.

The importance of this study lies in the fact that instruction on multi-word verbs has positive effects on EAP learners' presentations. There was a point in teaching multi-word verbs to EAP learners and the outcomes of the study display that they are able to reach near-native proficiency in giving their presentations in most of the mentioned aspects since these verbs are a significant aspect of the English language. However, more sessions and instruction on these verbs could lead to greater results and more proficiency levels for learners. They used in nearly all registers, and are regularly more common in academic spoken language than academic written language (e.g., Biber et al., 1999; Siyanova \& Schmitt, 2007). 
The students semantic and syntactic performances of the three subcategories suggest that their usage and how they vary from each other in the content. However, it is not easy to distinguish between the subcategories (Biber et al., 1999).

There is a concern that multi-word verbs cannot be simply learned via normal language activities and experiences as there are many syntactical complexities for learners (Coady, 1997). Hence, non-native English academic presenters, especially teachers and students of EAP classes, need to be well-informed about these issues in order to do their academic presentations more appropriately in the way the native speakers of English do.

The outcomes of this study also have implications for academic lecturers to become aware of different aspects of using these verbs. They are used in dissimilar ways in different formal and informal contexts. The outcomes of the study imply the effect of teaching courses on English learners' performance in their presentations. EAP course designers need to distinguish them for instruction as important lexical items. The results illustrate how these verbs are important in native academic contexts and how they should be taught in EAP courses and textbooks. In addition, the knowledge of multi-word verbs might help academic presenters to understand, create, and connect speech with greater ease. The findings can also enlighten those learners who want to develop their presentation comprehension process for a more successful academic career. They are recommended to dedicate much more consideration to the importance of the presentations which are highlighted by the multiword verbs.

\section{REFERENCES}

Altenberg, B. 1998. On the Phraseology of Spoken English: The Evidence of Recurrent Word Combinations. In A. Cowie (Eds.). Phraseology: Theory, Analysis and Applications. Oxford: Oxford University Press. 101-122.

Biber, D. 2006. University Language: A Corpus-based Study of Spoken and Written Registers. Amsterdam/Philadelphia: John Benjamins.

Biber, D., Conrad, S., \& Leech, G. 2002. Student Grammar of Spoken and Written English. London, England: Longman.

Biber, D. and Conrad, S. 1999. Lexical Bundles in Conversation and Academic Prose. In H. Hasselga rd and S. Oksefjell (Eds.). Out of Corpora: Studies in Honour of Stig Johansson. Amsterdam: Rodopi. 181-190.

Biber, D., Johansson, S., Leech, G., Conrad, S., \& Finegan, E. 1999. Longman Grammar of Spoken and Written English. London, England: Longman.

Boyd, F. A. 1989. Developing Presentation Skills: A Perspective Derived from Professional Education. English for Specific Purposes. 8(2): 195-203.

Cambridge Dictionaries Online. Available on October 15, 2015 at http://dictionary.cambridge.org/us/dictionary/american-english/.

Carter-Thomas, S., \& Rowley-Jolivet, E. 2001. Syntactic Differences in Oral and Written Scientific Discourse: The Role of Information Structure. ASP. 31/33: 19-37.

Chen, M. 2013. Overuse or Underuse: A Corpus Study of English Phrasal Verb Use by Chinese, 
British and American University Students. International Journal of Corpus Linguistics. 18(3): 418-442.

Coady, J. 1997. L2 Vocabulary Acquisition: A Synthesis of the Research. In J. Coady \& T. Huckin (Eds.). Second Language Vocabulary Acquisition Cambridge: Cambridge University Press. 272290.

Condon, N., \& Kelly, P. 2002. Does Cognitive Linguistics Have Anything to Offer English Language Learners in Their Efforts to Master Phrasal Verbs? I.T.L.137/138: 205-231.

Crawford-Camiciottoli, B. 2004. Interactive Discourse Structuring in L2 Guest Lectures: Some Insights from a Comparative Corpus-based Study. Journal of English for Academic Purposes. $3(1): 39-54$.

Csomay, E. 2006. Academic Talk in American University Classrooms: Crossing the Boundaries of Oral - Literate Discourse. Journal of English for Academic Purposes. 5(2): 117-135.

Csomay, E. 2007. A Corpus-based Look at Linguistic Variation in Classroom Interaction: Teacher Talk Versus Student Talk in American University Classes. Journal of English for Academic Purposes. 6(4): 336-355.

Csomay, E. 2015. A Corpus-based Analysis of Linguistic Variation in Teacher and Student Presentations in University Settings. In V. Cortes, \& E. Csomay (Eds.). Corpus-based Research in Applied Linguistics: Studies in Honor of Doug Biber Amsterdam/Philadelphia: John Benjamins. 1-23.

Dagut, M., \& Laufer, B. 1985. Avoidance of Phrasal Verbs: A Case for Contrastive Analysis. Studies in Second Language Acquisition. 7(01): 73-79.

Davies, M. 2008. The Corpus of Contemporary American English. Provo, UT: Brigham Young University. Available on October 15, 2015 at http://www.americancorpus.org/.

Darwin, C. M., 8c Gray, L. S. 1999. Going after the Phrasal Verb: An Alternative Approach to Classification. TESOL Quarterly. 33(1): 65-83.

Duan, M. \& Qin, X. 2012. Collocation in English Teaching and Learning. Theory and Practice in Language Studies. 2(9): 1890-1894.

Ellis, N. C. 1996. Sequencing in SLA: Phonological Memory, Chunking, and Points of Order. Studies in Second Language Acquisition. 18 (1): 91-126.

Erman, B., \& Warren, B. 2000. The Idiom Principle and the Open-choice Principle. Text. 20(1): 2962.

Fadanelli, S. B. 2012. A Corpus study on Brazilian Learners' Usage of English Phrasal Verbs. Revista Estudos Anglo-Americanos. n. 37.

Firth, A. 1957. Papers in Linguistics.. London: Oxford University Press. 1934-1951.

Folse, K. 2004. Vocabulary Myths: Applying Second Language Research to Classroom Teaching. Ann Arbor: The University of Michigan Press.

Freeborn, D. 1995. A Course Book in English Grammar. London: Macmillan.

Gardner, D., \& Davies, M. 2007. Pointing Out Frequent Phrasal Verbs: A Corpus-based Analysis. TESOL Quarterly. 45(2): 339-359.

Granger, S. 1998. Prefabricated Patterns in Advanced EAP Writing: Collocations and Formulae. In A. P. Cowie (Eds.). Phraseology: Theory, Analysis, and Applications, Oxford University Press. 
145-160.

Halliday, M. A. K., \& Hasan. 2001. Cohesion in English. Beijing: Foreign Language Teaching and Research Press.

Houshyar, S., \& Talebinezhad, M. 2012. Study on Avoidance Behaviour among Persian EAP

Learners: Phrasal Verbs in Focus. Greener Journal of Educational Research. 3(6): 238-248.

Hulstijn, J. H., \& Marchena, E. 1989. Avoidance: Grammatical or Semantic Causes? Studies in Second Language Acquisition. 11(3): 241-255.

Kamarudin, R. 2013. A Study on the Use of Phrasal Verbs by Malaysian Learners of English. Unpublished PhD Dissertation at the University of Birmingham, UK. Available at: http://etheses.bham.ac.uk/4504/1/Kamarudin13PhDl.pdf.

Laufer, B., \& S. Eliasson. 1993. What Causes Avoidance in Second Language Learning: L1-L2, Difference, L1-L2 Similarity, or L2 Complexity? Studies in Second Language Acquisition. 15(1): 35-48.

Lewis, M. 1993. The Lexical Approach: The State of ELT and a Way Forward. London: Heinle.

Lewis, S. 2001. Measuring Corporate Reputation. Corporate Communications: An International Journal. 6(1): 31-35.

Liao, Y., \& Fukuya, J. Y. 2004. Avoidance of Phrasal Verbs: The Case of Chinese Learners of English. Language Learning. 54(2): 193-226.

Liu, D. 2011. The Most-frequently Used English Phrasal Verbs in American and British English: A Multicorpus Examination. TESOL Quarterly. 45(4): 661-688.

Longman Dictionary of Contemporary English. Available on October 15, 2015 at http://www.ldoceonline.com/.

Maisa, S., Karunakoran, T. 2013. Idioms and Importance of Teaching Idioms to ESL Students: A Study on Teacher Beliefs. University of Hyderabad, India University of Jaffna, Sri Lanka. Asian Journal of Humanities and Social Sciences. 1(1): 110-122.

Mauranen, A. 2002. A Good Question': Expressing Evaluation in Academic Speech. In G. Cortese, \& P. Riley (Eds.). Domain-specific English: Textual Practices Across Communities and Classrooms Frankfurt: Peter Lang. 115-140.

Moon, R. 1997. Vocabulary Connections: Multi-word Items in English. In Schmitt, N. \& McCarthy, M. (Eds.). Vocabulary: Description, Acquisition and Pedagogy New York: Cambridge University Press. 40-63.

Moon, R. 1998. Frequencies and Forms of Phrasal Lexemes in English. In A. P. Cowie (Eds.). Phraseology: Theory, Analysis, and Applications. Oxford: Clarendon Press. 79-100.

Morton, J., \& Rosse, M. 2011. Persuasive Presentations in Engineering Spoken Discourse. Australasian Journal of Engineering Education. 17(2): 55-64.

Nattinger, J. and DeCarrico, J. 1992. Lexical Phrases and Language Teaching. Oxford University Press.

Nesselhauf, N. 2003. The Use of Collocations by Advanced Learners of English and Some Implications for Teaching. Applied Linguistics. 24(2): 223-242.

Nooj. Available on October 15, 2015 at http://www.nooj4nlp.net/pages/nooj.html.

OED Online. Oxford University Press. Available on April 14, 2016 at http://www.oed.com/.

Quirk, R., Greenbaum, S., Leech, G., \& Svartvik, J. 1985. A Comprehensive Grammar of the English 
Language. London: Longman.

Riguel, E. 2014. Phrasal Verbs: Usage and Acquisition. Athens Journal of Philosophy.

Robins, R. H. 2000. General Linguistics. Ed. 4. Beijing: Foreign Language Teaching and Research Press.

Rowley-Jolivet, E. 1999. The Pivotal Role of Conference Papers in the Network of Scientific Communication. ASP: La Revue du GERAS. 23-26: 176-196.

Schmitt, N. (Ed.). 2004. Formulaic Sequences: Acquisition, Processing and Use. Amster- dam: John Benjamins.

Siyanova, A., \& Schmitt, N. 2007. Native and Nonnative Use of Multi-word Vs. One-word Verbs. IRAL. 45: 119-139.

Siyanova-Chanturia, A. 2017. Researching the Teaching and Learning of Multi-word Expressions. Language Teaching Research. 21(3): 289-297.

Siyanova-Chanturia, A., Conklin, K., Caffarra, S., Kaan, E., and van Heuven, W. J. B. 2017. Representation and Processing of Multi-word Expressions in the Brain. Brain and Language. 175: 111-122.

Swales, J. M. 2001. Metatalk in American Academic Talk. Journal of English Linguistics. 29(1): 3454.

Swales, J. M. 2004. Research Genres: Explorations and Applications. Cambridge: Cambridge University Press.

Thompson, S. 2002. As the Story Unfolds: The Uses of Narrative in Research Presentations. In E. Ventola, C. Shalom, \& S. Thompson (Eds.). The Language of Conferencing Frankfurt: Peter Lang. 147-167.

Ventola, E., Shalom, C., \& Thompson, S. 2002. The Language of Conferencing. Frankfurt: Peter Lang. Wallace, M. J. 1982. Teaching Vocabulary. London: Heinemann Educational Books.

Wan Nur Asyura Wan Adnan and Maskanah Mohammad Lotfie. 2017. The Use of Adverbials in the Verbal Production of Malay ESL Learners: A Processability Approach. LSP International Journal. 4(1): 1-22.

Webber, P. 2005. Interactive Features in Medical Conference Monologue. English for Specific Purposes. 24(2): 157-181.

Weissberg, B. 1993. The Graduate Seminar: Another Research-process Genre. English for Specific Purposes. 12(1): 23-36.

Wells, J. C. 2006. English Intonation: An Introduction. Cambridge: Cambridge University Press.

Wood, D. 2004. An Empirical Investigation into the Facilitating Role of Automatized Lexical Phrases in Second Language Fluency Development, Journal of Language and Learning. 2(1): 27-50.

Wray, A. 2000. Formulaic Sequences in Second Language Teaching: Principle and Practice. Applied Linguistics. 21(4): 463-489.

Wray, A. 2002. Formulaic Language and the Lexicon. Cambridge: Cambridge University Press.

Wray, A. \& Perkins, M. 2000. The Functions of Formulaic Language: An Integrated Model. Language and Communication. 20(1): 1-28.

You, Y. 1999. Avoidance Phenomena of Phrasal Verbs by Korean Learners of English. English 
Teaching. 54(3): 135-155.

Zareva, A. 2009a. Informational Packaging, Level of Formality, and the Use of Circumstance Adverbials in L1 and L2 Student Academic Presentations. Journal of English for Academic Purposes. 8(1): 55-68.

Zareva, A. 2009b. Student Academic Presentations: The Processing Side of Interactiveness. English Text Construction. 2(2): 265-288.

Zareva, A. 2011. L2 Graduate Student Powerpoint Presentation Designs: A Reality Check. International Journal of Innovation and Learning. 9(2): 127-144.

Zareva, A. 2012a. Expression of Stance and Persuasion in Student Academic Presentations. In G. Mininni, \& A. Manuti (Eds.). Applied Psycholinguistics Milano, Italy: Franco Angeli. 316-323.

Zareva, A. 2012b. Lexical Composition of Effective L1 and L2 Student Academic Presentations. Journal of Applied Linguistics. 6(1): 91-110.

Zareva, A. 2013. Self-mention and the Projection of Multiple Identity Roles in TESOL Graduate Student Presentations: The Influence of the Written Academic Genres. English for Specific Purposes. 32(2): 72-83.

Zareva, A. 2016. Multi-word Verbs in Students' Academic Presentations. Journal of English for Academic Purposes. 23: 83-98. 